\title{
Causes of Atrial Fibrillation, its awareness and medication use in patients presented to peripheral hospital of KPK
}

\author{
ASFANDIYAR ${ }^{1}$, IKRAMULLAH ${ }^{2}$, JAVAIDULLAH ${ }^{3}$, MATIULLAH KHAN ${ }^{4}$, MUHAMNAD JAVID KHAN ${ }^{5}$, MEHMOD-UL- \\ HASSAN6 \\ ${ }^{1}$ District Cardiologist, ${ }^{2}$ Assistant Professor of Cardiology, Mardan Medical Complex, Mardan \\ ${ }^{3,5}$ Cardiologists, ${ }^{6}$ Professor of Cardiology, Hayatabad Medical Complex, Peshawar \\ ${ }^{4}$ District Cardiologist DHQ Teaching Hospital Swabi \\ Correspondence to Dr. Ikramullah ikramcardio@yahoo.com Cell 0313-4774433
}

\begin{abstract}
Aim: To observe the etiological causes of atrial fibrillation in local population at Mansehra, Pakistan.

Study design: Descriptive cross-sectional study

Place \& duration of study: DHQ Hospital Mansehra Pakistan from $1^{\text {st }}$ March 2017 to $30^{\text {th }}$ April 2018

Methods: Two hundred and fifty patients with atrial fibrillation were included in the study. Atrial fibrillation was diagnosed on 12 lead ECG, having irregularly irregular rhythm and no obvious $P$ waves found.

Results: Majority of patients (160) were females. Hypertension was the major cause of atrial fibrillation afflicting $35 \%$ patients while 25\% patients had mitral valve disease, $20 \%$ patients had heart failure and $10 \%$ patients had thyroid disorder as the cause of atrial fibrillation.

Conclusion: Atrial fibrillation commonly occurs in female and above 50 years old population and hypertension and mitral valve diseases are commonest causes.

Keyword: Atrial fibrillation, Hypertension, Mitral valve
\end{abstract}

\section{INTRODUCTION}

Atrial fibrillation is known as one of the common causes responsible for cardiovascular death and hospitalization and is having major health issue in public and also a major burden on health resources ${ }^{1,2,3}$.

Pakistan is having approximately 4 cases per 1000 population ${ }^{4}$. Majority of causes of atrial fibrillation are preventable. CHARGE-AF is one of the common models which were designed for USA population and Western Europe. This model was aimed to prevent occurrence of atrial fibrillation in population and was based mainly on important risk factors like age, race, weight, height, smoking, blood pressure and use of medications for blood pressure. Other factors like diabetes, history of myocardial infarction and heart failure were also considered ${ }^{5}$. Early identification of the risk factors and treating them well on time can prevent the atrial fibrillation and its outcomes ${ }^{6-10}$.

This study is will help to identify various causes of atrial fibrillation, awareness of the disease in community and types of medications used for its treatment.

\section{MATERIALS AND METHODS}

This study was performed at District Head Quarter Hospital of Mansehra Pakistan. Study was started on $1^{\text {st }}$ March in 2017 and data was collected till 30.4.2018. Total sample size was 250 . All patients included in the study was having atrial fibrillation. Atrial fibrillation was diagnosed on 12 lead ECG, having irregularly irregular rhythm and no obvious $P$ waves found. Detailed history and clinical examination, with all relevant investigation for the cause of AF were taken as by American guidelines for $\mathrm{AF}^{11,12}$. The data was entered and analyzed through SPSS-20.

Received on 12-08-2019

Accepted on 03-01-2020

\section{RESULTS}

The mean age was $59.7 \pm 14.6$. There were $160(64 \%)$ females and remaining were males. Causes of atrial fibrillation were studied and most common cause was hypertension and mitral valve disease (Table 1). Regarding awareness about Atrial fibrillation majority of patients (40\%) were unaware of their disease. Regarding stroke prevention, majority of patients were on aspirin only or no such treatment was used at hospital presentation (Table 2).

Table 1: Causes of atrial fibrillation $(n=250)$

\begin{tabular}{|l|c|c|}
\hline Etiology & $\mathbf{n}$ & \%age \\
\hline HTN & 87 & 35 \\
\hline Mitral valve & 62 & 25 \\
\hline Heart failure & 50 & 20 \\
\hline ACS & 11 & 4.4 \\
\hline Aortic valve & 4 & 1.6 \\
\hline Thyroid & 18 & 7.2 \\
\hline RTI & 2 & 0.8 \\
\hline HOCM & 2 & 0.8 \\
\hline Unknown & 9 & 3.6 \\
\hline COPD & 5 & 2 \\
\hline
\end{tabular}

Table 2: Drugs used for AF

\begin{tabular}{|l|c|c|}
\hline Drug & $\mathbf{n}$ & \%age \\
\hline No drug & 100 & 40.0 \\
\hline Aspirin & 100 & 40.0 \\
\hline Clopidogrel & 20 & 8.0 \\
\hline Warfarin & 5 & 2.0 \\
\hline Dual antiplatlet & 15 & 6.0 \\
\hline Rivoroxiban & 10 & 4.0 \\
\hline
\end{tabular}

\section{DISCUSSION}

In our study mean age for atrial fibrillation patients were 59.7 which is same is one found by Ikramullah et $\mathrm{al}^{13}$ in their study of mean age of 60.7 years. Majority $68 \%$ patients were females in a study performed in Turkish 
population, they found that majority of patients were hypertensive $(62.5 \%)$ as we found in our study (35\%) but there was different findings regarding second common cause of atrial fibrillation. In our study we found that mitral valve disease is the leading cause after hypertension $(25 \%)$ and in Turkish study coronary artery disease was the second commonest cause of Atrial fibrillation noted $(33 \%)^{10}$. Similarly a study conducted in USA found that hypertension is the commonest cause of Atrial fibrillation exactly we found in our study but similar to Turkish study they also found ischemic heart disease is the second common cause of atrial fibrillation ${ }^{11}$.

Regarding management of atrial fibrillation we found that most patients were unaware of their disease and those who were aware were only using aspirin in majority of cases. Tavassoli ${ }^{14}$ and Tulner $^{15}$ also found in their studies that upto $50 \%$ patient not receive proper anticoagulation treatment which means that proper antiocogulation practices are lacking in majority of places.

\section{CONCLUSION}

Atrial fibrillation is commonly undiagnosed and mistreated condition in this part of the world and usually common in patients with hypertension and mitral valve diseases.

\section{REFERENCES}

1. Miyasaka Y, Barnes ME, Gersh BJ, Cha SS, Bailey KR, Abhayaratna WP, Seward JB, et al. Secular trends in incidence of atrial fibrillation in Olmsted County, Minnesota, 1980 to 2000 , and implications on the projections for future prevalence. Circulation 2006;114:119-25.

2. Krijthe BP, Kunst A, Benjamin EJ, Lip GY, Franco $\mathrm{OH}$, Hofman $A$, et al. Projections on the number of individuals with atrial fibrillation in the European Union, from 2000 to 2060. Eur Heart J 2013;34:2746-51.

3. Chugh SS, Havmoeller R, Narayanan K, Rienstra M, Benjamin EJ, Gillum RF, Kim YH, et al. Worldwide epidemiology of atrial fibrillation: a Global Burden of Disease 2010 Study. Circulation 2014;129:837-47.

4. Alonso A, Krijthe BP, Aspelund T, Stepas KA, Pencina MJ, Moser $\mathrm{CB}$, et al. Simple risk model predicts incidence of atrial fibrillation in a racially and geographically diverse population: the CHARGE-AF consortium. J Am Heart Assoc 2013; 2(2):e000102.

5. Davis M, Rodgers S, Rudolf M, Hughes M, Lip GY, Guideline Development Group for the NICE clinical guideline for the management of atrial fibrillation. Patient care pathway, implementation and audit criteria for patients with atrial fibrillation. Heart 2007; 93(1):48.

6. Camm AJ, Lip GY, De Caterina R, Savelieva I, Atar D, Hohnloser SH, et al. 2012 focused update of the ESC Guidelines for the management of atrial fibrillation: an update of the 2010 ESC Guidelines for the management of atrial fibrillation. Developed with the special contribution of the European Heart Rhythm Association. Eur Heart J 2012;33:2719-47.

7. Akeroyd JM, Chan WJ, Kamal AK, Palaniappan L, Virani SS. Adherence to cardiovascular medications in the South Asian population: A systematic review of current evidence and future directions. World J Cardiol 2015;7:938-47.

8. Ganesan AN, Chew DP, Hartshorne T, Selvanayagam JB, Aylward. PE, Sanders $P$, et al. The impact of atrial fibrillation type on the risk of thromboembolism, mortality, and bleeding: a systematic review and meta-analysis. Eur Heart $\mathrm{J}$ 2016;37:1591-1602.

9. Banerjee A, Taillandier S, Olesen JB, Lane DA, Lallemand B, Lip GY, et al. Pattern of atrial fibrillation and risk of outcomes: the Loire Valley Atrial Fibrillation Project. Int $\mathrm{J}$ Cardiol 2013;167:2682-87.

10. Cogen EE, Tombul T, Yildirim G, Odabas FO, Sayin F. The role of atrial fibrillation on mortality and morbidity in patients with ischaemic stroke. J Pak Med Assoc 2013; 1516-9.

11. January CT, Wann LS, Alpert JS, Calkins H, Cigarroa JE, Cleveland JC Jr, et al. AHA/ACC/HRS guideline for the management of patients with atrial fibrillation: executive summary: a report of the American College of Cardiology/American Heart Association Task Force on practice guidelines and the Heart Rhythm Society. Circulation 2014;130(23):2071-104.

12. Mohammad AS, Kundi A. Guideline recommended pharmacological management of patients with atrial fibrillation, a t a tertiary care cardiac centre, Karachi Pakistan are we practicing what we teach"? Pak Heart J 2013; 46(4): 243-9.

13. Ullah I, Ahmad F, Ahmad S, hayat Y. atrial fibrillation and stroke prevention practices in patients who are candidates for anticoagulation. J Ayub Med Coll.215:27;3:269-27

14. Tvassoli N, Perrin A, Bérard E, Gillette S, Vellas B, Rolland Y, et al. Factors associated with undertreatment of atrial fibrillation in geriatric outpatients with Alzheimer disease. Am J Cardiovasc Drugs. 2013;13(6):425-33

15. Tulner LR, Van Campen JP, Kuper IM, Gijsen GJ, Koks CH, Mac Gillavry MR, et al. Reasons for undertreatment with oral anticoagulants in frail geriatric outpatients with atrial fibrillation: a prospective, descriptive study Drugs Aging 2010;27(1):39-50. 